\title{
Prolonged heat stress of Lactobacillus paracasei GCRL163 improves binding to human colorectal adenocarcinoma HT-29 cells and modulates the relative abundance of secreted and cell-surface located proteins
}

Kayode T. Adu*广, Richard Wilson ${ }^{+}$, Anthony L. Baker ${ }^{\dagger}$, John P. Bowman ${ }^{\dagger}$ and Margaret L. Britz $^{*}$

$\dagger$ Tasmanian Institute of Agriculture, University of Tasmania, Hobart, Tasmania 7001, Australia.

\$ Central Science Laboratory, University of Tasmania, Hobart, Tasmania 7001, Australia.

*Corresponding Author

E-mail: kayode.adu@utas.edu.au,aduktus@gmail.com

Phone: +61449855379

\section{Supporting Information, Supplementary Figures}

Supporting information Figure S1: DNA release from cells of Lactobacillus paracasei GCRL163 following different treatments for extracting surface proteins and peptides, monitored using DNA fragment analysis.

Supporting information Figure S2: Heat maps showing the distribution of cell surface proteins into predicted subcellular locations for L. paracasei GCRL163 and their relative abundance at different growth temperatures.

Supporting information Figure S3: Heat maps depicting changes in abundance trends in functional groups of protein in extracts prepared by (A) trypsin shaving and (B) LiCl-sucrose extraction from L. paracasei GCRL163.

Supporting information Figure S4: Protein structural and ligand binding modelling of PspCdomain proteins from L. casei and S. pneumoniae (A) and $\alpha$-fucosidase from L. casei (B). Supporting information Figure S5: Images of Gram-stained Lactobacillus strains adhering to HT-29 cells. (A) L. helveticus K1 (B) L. rhamnosus NBRC3425 (C) L. paracasei GCRL163 and (D) L. paracasei 7K07A2. 
Supporting information Figure S6: Changes in relative abundance of proteins in cell-free lysates, LiCl-sucrose and trypsin shaving extracts for proteins in the genomic region around the presumptive L. casei adhesin, YthC/PspC.

Supporting information Figure S7: Schematic of relative abundance changes of proteins putatively involved in $N$-acetylgalactosamine degradation in L. paracasei GCRL163.

Supporting information Table S1: Spreadsheets showing all proteins which met the filtering criteria (.xlsx).

Supporting information Table S2: MaxQuant data for all peptides detected (proteinGroup.txt and peptides.txt files) (.xlsx).

Supporting information Table S3: LFQ differences relative to the control cultured at $30^{\circ} \mathrm{C}$ for surface proteins detected in LS, TS and ECF fractions and the corresponding CFEs (.xlsx). 


\section{Supporting Information Figure S1}

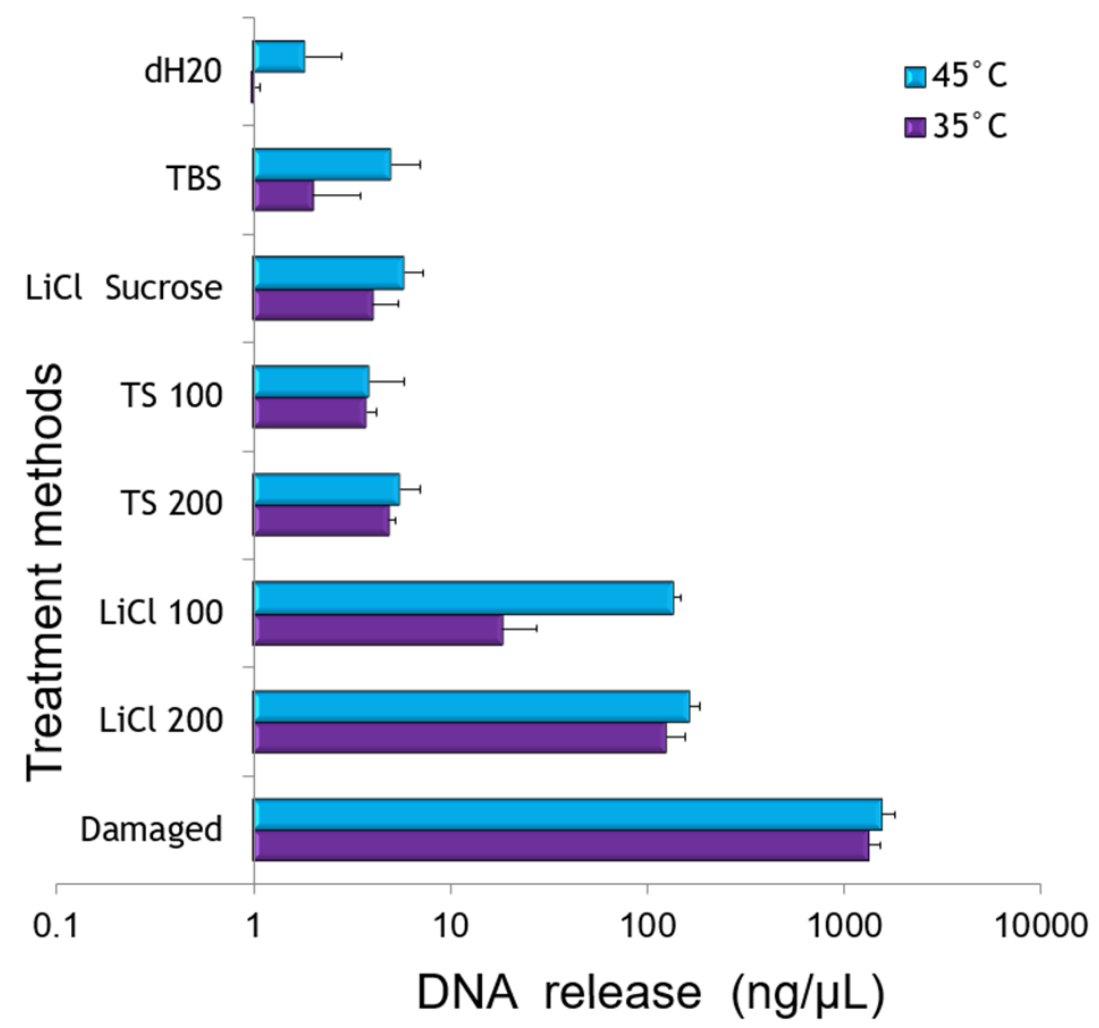

Figure S1. DNA release from cells of Lactobacillus paracasei GCRL163 following different treatments for extracting surface proteins and peptides, monitored using DNA fragment analysis. Mid-exponential cells were harvested following culture in MRS in bioreactors with $\mathrm{pH}$ controlled at 6.5 and temperatures of $30^{\circ} \mathrm{C}$ to $45^{\circ} \mathrm{C}$. Damaged: cells lysed by bead beating; L200: whole cells treated with $\mathrm{LiCl}$ in Tris buffer at $200 \mathrm{rpm}$ agitation; L100: whole cells treated with $\mathrm{LiCl}$ in Tris buffer at $100 \mathrm{rpm}$ agitation; TS200: whole cells trypsin shaved in Tris buffer/40\% sucrose at 200 rpm agitation; TS100: whole cells trypsin shaved in Tris buffer/40\% sucrose at $100 \mathrm{rpm}$ agitation; LS: whole cells treated with $\mathrm{LiCl}$ Tris buffer/40\% sucrose, no agitation except occasional cell resuspension of settled cells; TBS: whole cells treated with Tris buffer/40\% sucrose; and dH20: whole cells treated with distilled water, no buffering. 


\section{Supporting Information Figure S2}

A

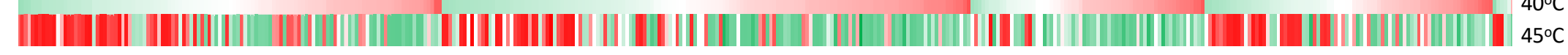

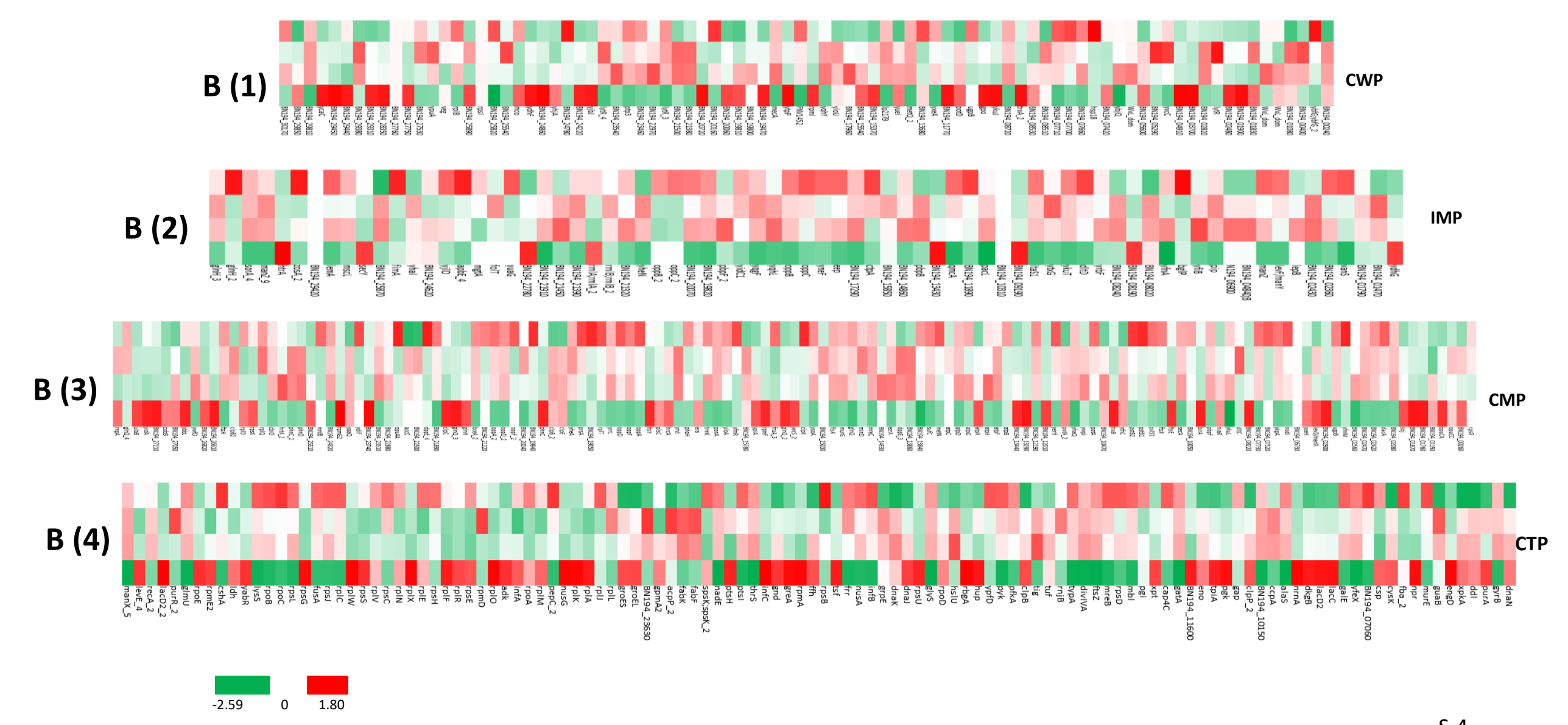


Figure S2. Heat maps showing the distribution of cell surface proteins into predicted subcellular locations for L. paracasei GCRL163 and their relative abundance at different growth temperatures. Protein are named by gene locus number or gene name, ordered right to left by locus number. The heat maps represent normalized, log-transformed mean Z-scores at different growth temperatures of $30^{\circ} \mathrm{C}$ to $45^{\circ} \mathrm{C}$, with the layout in panels (B1-4) in temperature order shown in (A). Z-scores are for proteins in the LiCl-sucrose extracts. (A) all the identified cell surface proteins from extracts prepared by trypsin shaving, LiCl-sucrose extraction and ECF fractions; (B1) proteins identified as cell-wall associated (CWP); (B2) proteins displaying between 1 and $12 \alpha$-helical TMDs and identified as integral membrane proteins (IMP); (B3) proteins identified as cell membrane-anchored (CMP); (A4) cytoplasmic-surface associated proteins (CTP). Protein subcellular localization was assigned according to bioinformatic prediction tools: integral membrane proteins were predicted as proteins possessing transmembrane domains using TMHMM server 2.0 algorithm. Cytoplasmic proteins were predicted as intracellular proteins with no exporting or sorting signal and cell wall-associated proteins were predicted as proteins possessing cell wall-binding or LPXTG domains as established by Gpos-mPLoc and PSORTb 3.0.2 algorithms. 


\section{Supporting Information Figure S3}
A $\begin{aligned} & 000 \\ & 000 \\ & 0\end{aligned}$
Transcription-associated $A B C$ type transporter systems tRMA ribosome assembly Transcriptional regulation tRMA Aminoacyl synthesis DNA repar and replication Cell defense and detorification RNA Polymerase
Frotein export
Protein translation
Phosphotransferase systems
Glycolysistntermediary
Protein folding and turnover
RNA degradation
Cytoknesis
Fibosomal protens
General prediction
Cell wall biogenesis
Livid-related metabolism
Membrane bioenergetics
Uncharacterized Niclec acidinucleotide metabobism

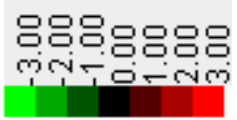

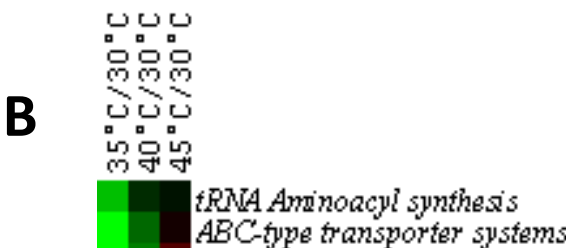
Amino acid related
Tricarbo yylic acid pathway
RMA degradation
DNA repair
Transcription-associated
Frotein translation
tRTA ribosome assembly
Ribosomal protans
DNA replication
St gnal transduction
Ricleic acidinucleotide metabohsm
Frotein export
Cell wall bogenesis
Other transporter proteins
Cell defense and detorification
Protein folding and turnover
Phosphotransferase systems
Membrane bioenergetics
Central glycolysisfintermediary
General prediction
Cofactor related metabobism
RNA Polymerase
Carbohydrate related metabolism
Transcriptional regulation
Posttranslational modification
Uncharacterized
Cytokinesis
Ijpid-related metabolism
Cell surface vroteins

Figure S3. Heat maps depicting changes in abundance trends in functional groups of protein in extracts prepared by (A) trypsin shaving and (B) LiCl-sucrose extraction from L. paracasei GCRL163. Differences are based on $t$-test values derived from T-profiler analysis at different temperatures $\left(35^{\circ} \mathrm{C}, 40^{\circ} \mathrm{C}, 45^{\circ} \mathrm{C}\right.$ compared to $\left.30^{\circ} \mathrm{C}\right)$ using Cluster v.3.0 software. The overall proteomic data at different temperatures were compared to the protein functional groups using unsupervised hierarchical clustering on the basis of uncentered correlation. Analysis of the proteins based on the functional classification as indicated by the colour scale on the basis of $t$-values revealed differentially expressed proteins. For (B), the data contained all of the 826 proteins in the LS extract.

\section{Supporting Information Figure S4}



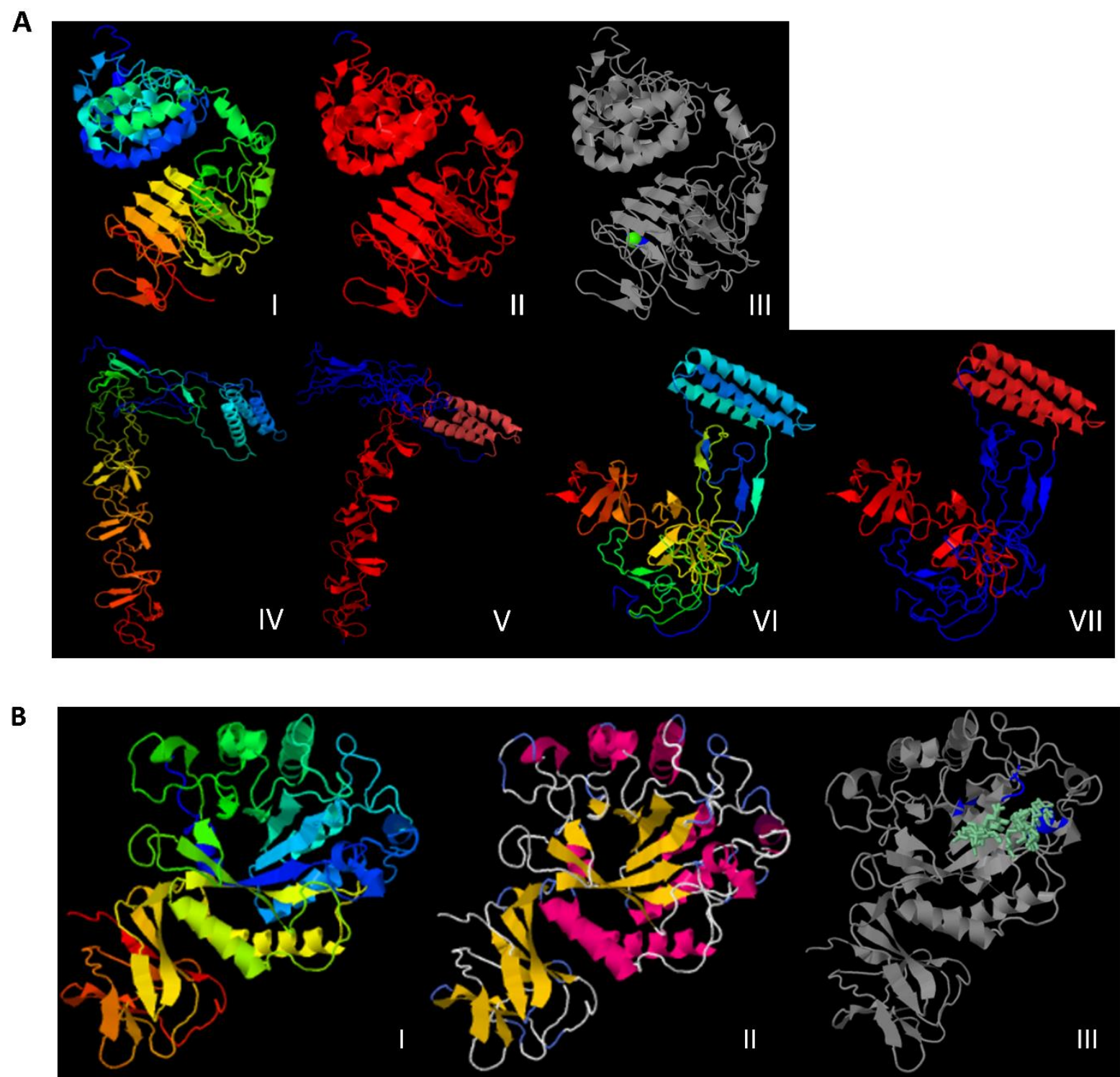

Figure S4: Protein structural and ligand binding modelling of PspC-domain proteins from $L$. casei and Streptococcus pneumoniae (A) and $\alpha$-fucosidase from L. casei (B). Structural and ligand binding modelling was performed using the Phyre2 platform (http://www.sbg.bio.ic.ac.uk/phyre2) as described previously ${ }^{38}$. Panel A, I-III: L. casei YthC/PspC-domain protein based on the FASTA sequence for protein CCK21977 in L. casei W56 (ORF BN194_10300, UniProt). Panel A, IV and V: Streptococcus pneumoniae (A0A0T8BZF2_STREE, ORF ERS020474_00503, UniProt), surface protein PspC, GO mannosyl-glycoprotein endo- $\beta-N$-acetylglucosaminidase activity; Panel A, VI and VII: $S$. 
pneumoniae (D2JYB7_STREE, UniProt), PspC. Panel B: $\alpha$-fucosidase model based on the FASTA sequence for L. paracasei LC2W protein (AEA55152.1) which has 100\% sequence identity with the protein detected in extracts of strain GCRL163 and is equivalent to protein WP_012492060.1 in L. casei BL23. The protein in strain W56 is specified by two ORFs, suggesting the gene is split or there is a sequencing error, so an alternative sequence, which is common in the L. casei group including GCRL163, was selected for modelling.

Ribbon models (A I, IV and VI; B I) show N to C terminal coloured blue to red; evaluation of confidence (A II,V and VII) shows regions modelled with high confidence in red, low confidence in blue. 99\% of the residues in the L. casei YthC/PspC putative adhesin and in the $\alpha$-fucosidase were modelled with $>90 \%$ confidence. $47 \%$ of residues in $S$. pneumoniae PspC A0A0T8BZF2_STREE and 50\% in PspC D2JYB7_STREE were modelled with >90\% confidence; Grey images (A III, B III) show ligand binding sites. The predicted ligand in (A III) is $\mathrm{Ca}$ and the predicted ligands in (B III) are glucose and $N$-acetylgalactosamine; secondary structure is shown for the $\alpha$-fucosidase in (B II). Highest confidence templates used in creating models were (PDB identity): 4qrk (L. casei adhesin); 2bib, ev04, 4k12 (S. pneumoniae PspC); 6gn6 (L. casei $\alpha$-fucosidase). 


\section{Supporting Information Figure S5}

(3)

4

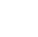

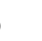

7

(1)

1

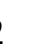

Figure S5. Images of Gram-stained Lactobacillus strains adhering to HT-29 cells. (A) L. helveticus K1 (B) L. rhamnosus NBRC3425 (C) L. paracasei GCRL163 and (D) L. paracasei 7K07A2. Images from approximately 60\% confluence regions were examined to allow for clarity (X100 magnification).
B

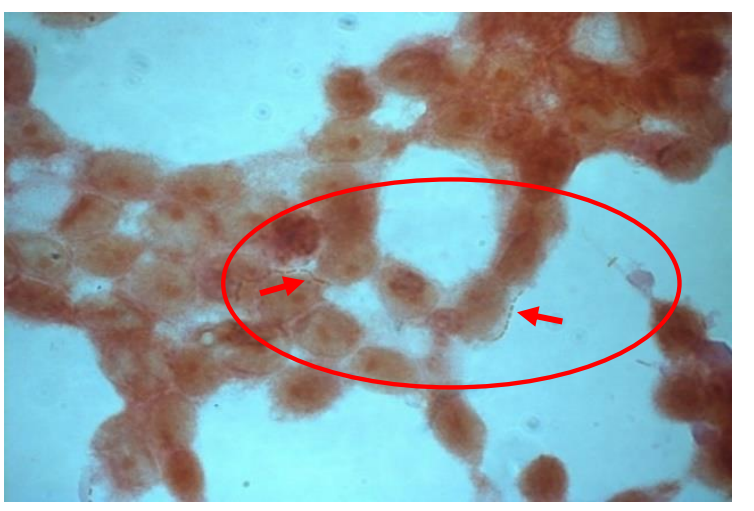

C

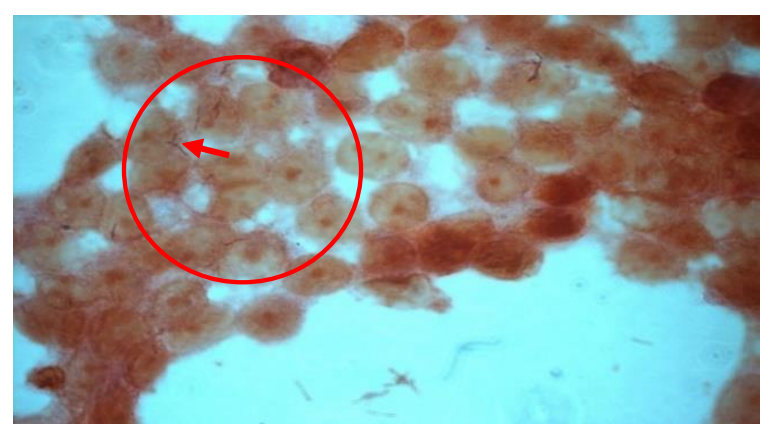

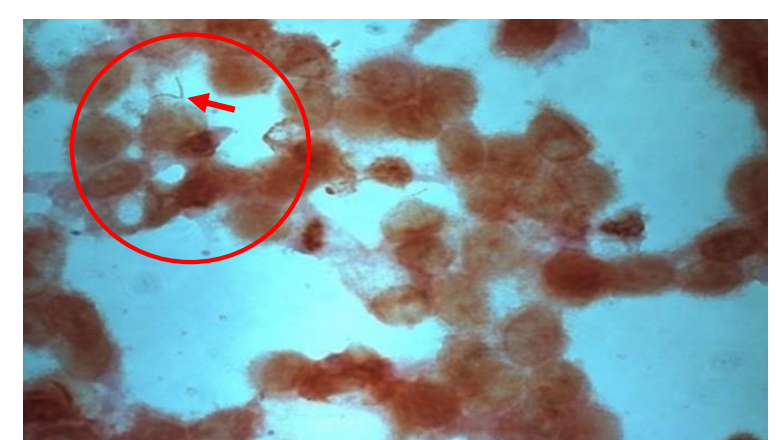

A

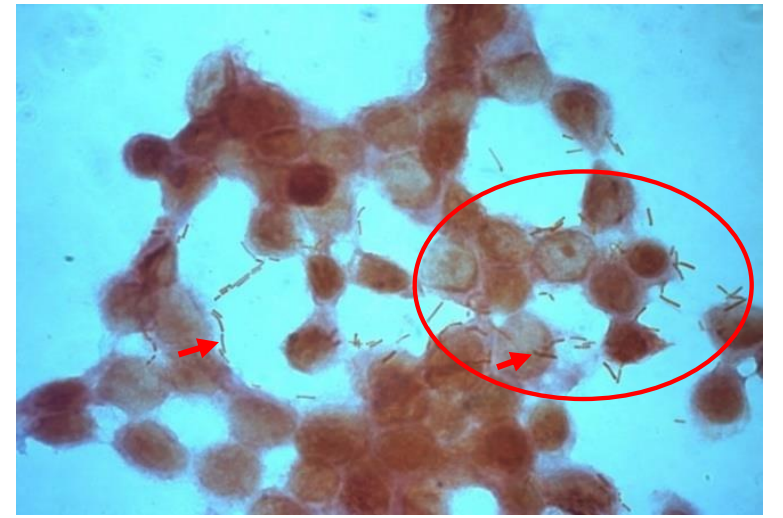

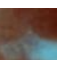




\section{Supporting Information Figure S6}

A
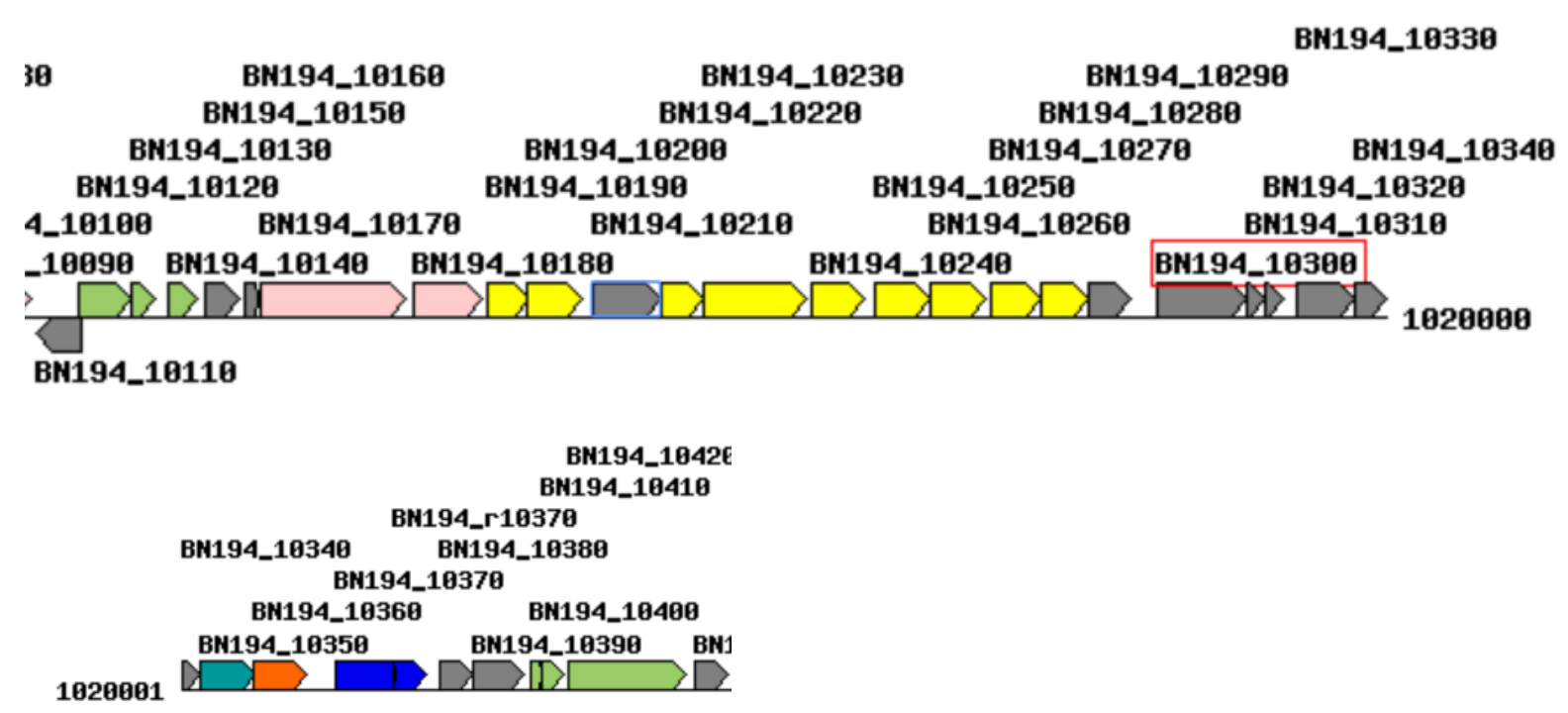

B

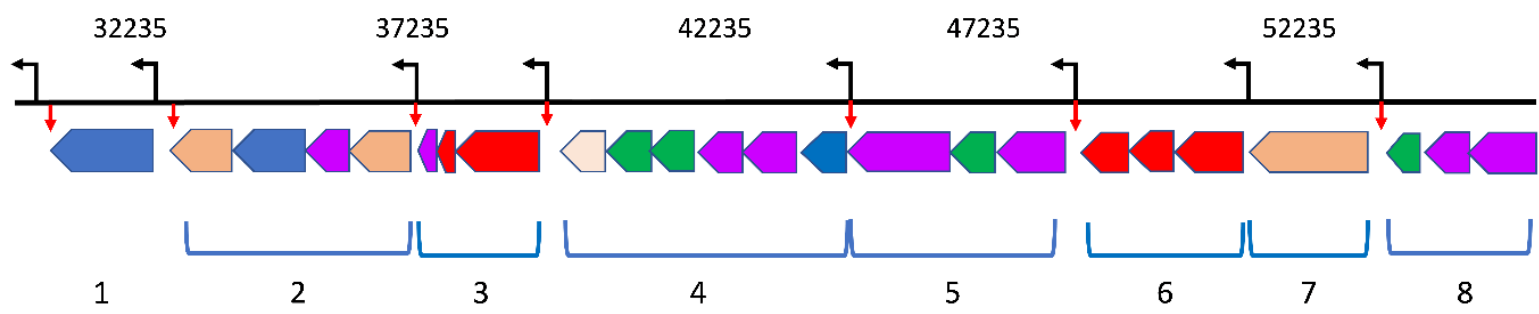

Figure S6: Changes in relative abundance of proteins in cell-free lysates, LiCl-sucrose and trypsin shaving extracts for proteins in the genomic region around the presumptive L. casei adhesin, YthC/PspC. Panel (A) shows the genome layout for L. casei W56, from KEGG GENE with the genome map generated from the BLAST search of the FASTA sequence of BN194_10300 (red box, gene encodes the YthC/PspC protein) using the embedded analytical tools (https://www.genome.jp/kegg); panel (B) shows the genome layout for L. paracasei GCRL163 and protein abundance changes detected in proteomic data for cells cultured at 40 and $45^{\circ} \mathrm{C}$ relative to $30^{\circ} \mathrm{C}$. The layout is from the scaffold in the genome sequence of GCRL163 from IMG (https://img.jgi.doe.gov) (scaffold source Lactobacillus casei GCRL163 : Ga0183009_1328, 120136bp) and was obtained by locating the phosphoglucomutase (locus 
tag Ga0183009_132830) through function searching. The neighbour position numbers are assigned by IMG. Sequences for intergenic regions were examined for the presence of promoters using the BPROM tool (http://www.softberry.com) and rho-independent terminators were predicted using the Arnold Finding Terminators tool (http://rssf.i2bc.paris-

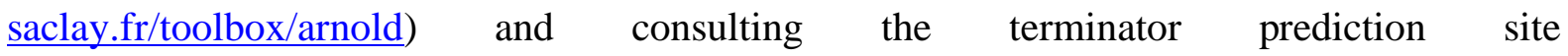
(transterm.cbcb.umd.edu/tt/Lactobacillus_casei.tt) for the complete genome sequence of $L$. casei BL23 (gi|191636824). Codes for expression level colours and symbols are:

Blue: no change in $\log _{2} \mathrm{LFQ}$ relative to control at $30^{\circ} \mathrm{C}\left(\log _{2}\right.$ differences $\left.< \pm 0.5\right)$

Orange: pale orange, $\log _{2}$ difference $=0.6-0.9$; dark orange $=\log _{2}$ difference $=1-1.9$, indicating upregulation at elevated culture temperature 40 and/or $45^{\circ} \mathrm{C}$

Red: $\log _{2}$ differences $=2-4$, indicating strong up-regulation at 40 and $/$ or $45^{\circ} \mathrm{C}$

Green: $\log _{2}$ differences $=-0.8-(-2.8)$, indicating down-regulation of proteins at 40 and/or $45^{\circ} \mathrm{C}$

Purple: protein was not detected in proteomic data in any cellular fraction

Black arrows: promoters detected in intergenic regions

Red arrows: terminators detected in intergenic regions.

The bracketed clusters 1-8 in (B) show operons predicted on the basis of the presence of promoters and terminators in the intergenic regions. Gene identity/protein function is according to gene locus numbers in strain W56 as tabulated below.

\begin{tabular}{|c|c|c|c|c|c|}
\hline \multicolumn{6}{|c|}{ Code for gene locus numbers and protein identity } \\
\hline $\begin{array}{l}\text { Cluster } \\
\text { number }\end{array}$ & Gene locus & $\begin{array}{l}\text { Protein } \\
\text { name }^{\mathrm{a}}\end{array}$ & $\begin{array}{ll}\begin{array}{l}\text { Function } \\
\text { domain }^{\mathrm{a}}\end{array} & \text { or } \\
\end{array}$ & Comment & $\begin{array}{l}\text { Cell } \\
\text { fraction }^{b}\end{array}$ \\
\hline 1 & BN194_10370 & $\mathrm{Pgm} / \mathrm{PgcA}$ & Phosphoglucomutase & & CFE, LS \\
\hline \multirow[t]{4}{*}{2} & BN194_10360 & TrxB & Thioredoxin reductase & & $\mathrm{CFE}$ \\
\hline & BN194_10350 & GpsA & $\begin{array}{l}\text { Glycerol-3-phosphate } \\
\text { dehydrogenase }\end{array}$ & & CFE, LS \\
\hline & BN194_10340 & Lgt & $\begin{array}{l}\text { Prolipoprotein } \\
\text { diacylglyceryl transferase }\end{array}$ & & $\mathrm{ND}^{\mathrm{c}}$ \\
\hline & BN194_10330 & HprK & $\begin{array}{l}\text { Hpr (serine) } \\
\text { kinase/phosphorylase }\end{array}$ & & CFE \\
\hline \multirow[t]{3}{*}{3} & BN194_10320 & $\begin{array}{l}\text { Predicted } \\
\text { membrane } \\
\text { protein }\end{array}$ & $\begin{array}{l}\text { Pfam: PF04020.13, } \\
\text { Phage_holin_4_2 }\end{array}$ & $\begin{array}{l}\text { The function of } \\
\text { holins putatively } \\
\text { include providing } \\
\text { transport of murein } \\
\text { hydrolases across } \\
\text { the cell membrane } \\
\text { to access cell wall } \\
\text { polymers as a } \\
\text { prelude for lysis. } \\
\text { Autolysins. }\end{array}$ & ND \\
\hline & BN194_10310 & Uncharacterised & $\begin{array}{l}\text { Phage_holin_3_6 } \\
\text { PF07332.11 }\end{array}$ & As above & $\begin{array}{l}\text { TS (only } \\
\text { detected in TS, } \\
\left.45^{\circ} \mathrm{C}\right)\end{array}$ \\
\hline & BN194_10300 & YthC/PspC & DUF4097 & $\begin{array}{lr}\text { Domain contains a } \\
\text { highly } & \text { conserved } \\
\text { repeating } & \text { GD, gly- }\end{array}$ & $\begin{array}{l}\text { TS (regulatory } \\
\text { changes only } \\
\text { seen in TS) }\end{array}$ \\
\hline
\end{tabular}




\begin{tabular}{|c|c|c|c|c|c|}
\hline & & & & $\begin{array}{l}\text { asp, motif. It may } \\
\text { form part of a } \\
\text { bacterial adhesin. }\end{array}$ & \\
\hline \multirow[t]{6}{*}{4} & BN194_10290 & PhoU & $\begin{array}{l}\text { Phosphate uptake } \\
\text { regulator }\end{array}$ & & $\mathrm{CFE}$ \\
\hline & BN194_10280 & PstB2 & $\begin{array}{l}\text { Phosphate import ATP- } \\
\text { binding protein PstB } 2\end{array}$ & & $\begin{array}{l}\text { LS (only } \\
\text { detected in LS) }\end{array}$ \\
\hline & BN194_10270 & PstB1 & $\begin{array}{l}\text { Phosphate import ATP- } \\
\text { binding protein PstB } 1\end{array}$ & & $\begin{array}{l}\text { LS (only } \\
\text { detected in LS) }\end{array}$ \\
\hline & BN194_10260 & YqgI & $\begin{array}{l}\text { Probable } \mathrm{ABC} \text { transporter } \\
\text { permease protein }\end{array}$ & & ND \\
\hline & BN194_10250 & YqgH & $\begin{array}{l}\text { Probable } \mathrm{ABC} \text { transporter } \\
\text { permease protein yqgH }\end{array}$ & & ND \\
\hline & BN194_10240 & PstS1 & $\begin{array}{l}\text { phosphate transport } \\
\text { system substrate-binding } \\
\text { protein }\end{array}$ & & $\begin{array}{l}\text { LS (only } \\
\text { detected in LS) }\end{array}$ \\
\hline \multirow[t]{3}{*}{5} & BN194_10230 & PhoR & $\begin{array}{l}\text { two-component system, } \\
\text { OmpR family, phosphate } \\
\text { regulon sensor histidine } \\
\text { kinase }\end{array}$ & & ND \\
\hline & BN194_10220 & PhoP & $\begin{array}{l}\text { two-component system, } \\
\text { OmpR family, alkaline } \\
\text { phosphatase synthesis } \\
\text { response regulator }\end{array}$ & & CFE \\
\hline & BN194_10210 & MinJ & $\begin{array}{l}\text { Probable cell division } \\
\text { topological determinant }\end{array}$ & & ND \\
\hline \multirow[t]{3}{*}{6} & BN194_10200 & FtsX & $\begin{array}{l}\text { cell division transport } \\
\text { system permease protein }\end{array}$ & & CFE \\
\hline & BN194_10190 & FtsE & $\begin{array}{l}\text { cell division transport } \\
\text { system ATP-binding } \\
\text { protein }\end{array}$ & & CFE, TS \\
\hline & BN194_10180 & PrfB & $\begin{array}{lll}\text { peptide } & \text { chain } & \text { release } \\
\text { factor } 2 & & \\
\end{array}$ & & CFE \\
\hline 7 & BN194_10170 & $\operatorname{Sec} A$ & $\begin{array}{ll}\text { preprotein } \\
\text { subunit }\end{array}$ & & CFE, TS \\
\hline \multirow[t]{3}{*}{8} & BN194_10150 & $\mathrm{Hpf}$ & $\begin{array}{l}\text { Ribosome hibernation } \\
\text { promoting factor }\end{array}$ & $\begin{array}{l}\text { Ribosome } \\
\text { associated } \quad \sigma^{54} \\
\text { modulation protein }\end{array}$ & CFE, LS \\
\hline & BN194_10140 & ComFC & Competence protein FC & $\begin{array}{l}\text { Competence-related } \\
\text { DNA } \\
\text { transformation } \\
\text { transporter (DNA- } \\
\text { T) core component }\end{array}$ & ND \\
\hline & BN194_10130 & ComFA & competence protein FA & & ND \\
\hline \multicolumn{6}{|c|}{$\begin{array}{l}\text { a Abbreviations and motif information are from KEGG Gene and UniProt, with reference to the } \\
\text { annotated genome of GCRL163 } \\
\text { b Cell fraction where } \log _{2} \text { differences were recorded in the gene layout map in (B). Cell-free extract } \\
\text { (CFE) MaxQuant data have been published previously }{ }^{38} \text { and changes in abundance in LiCl-sucrose } \\
\text { (LS) extracts or trypsin shaving preparations (TS) are found in Table S3. } \\
\text { c ND = not detected in any cell fraction } \\
{ }^{d} \text { BN194 } 10160 \text { is found in the W56 genome but not in the genome of GCRL163 }\end{array}$} \\
\hline
\end{tabular}




\section{Supporting Information Figure S7}

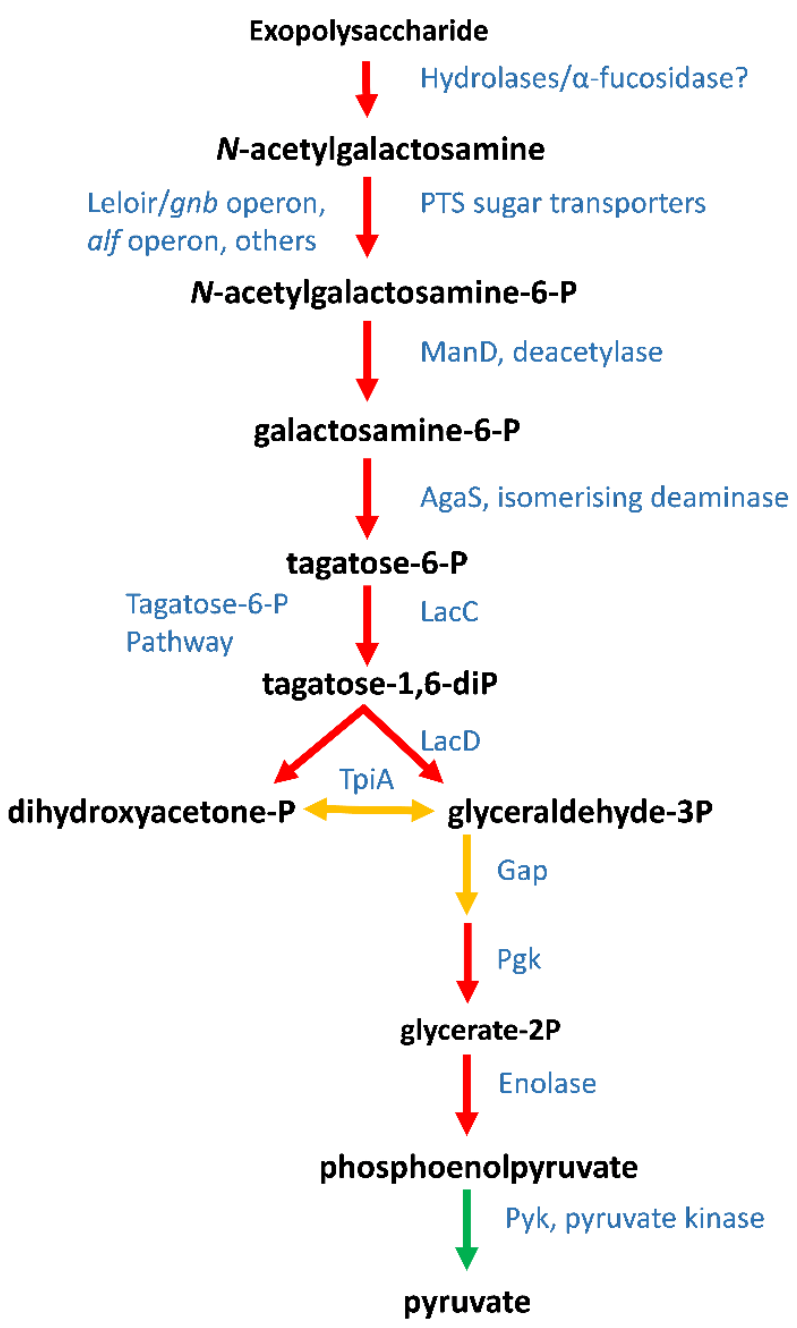

Figure S7. Schematic of relative abundance changes of proteins putatively involved in $\mathrm{N}$ acetylgalactosamine degradation in L. paracasei GCRL163. See Figure S6 for definition of colour code for arrows. 